\title{
Preliminary observations on culture potentials of Indian white prawn (Penaeus indicus) in low saline earthen ponds
}

\author{
MD. MOTIUR RAHMAN*, H.M. RAKIBUL ISLAM, MD. AMIRUL ISLAM, \\ MD. LATIFUL ISLAM, A.F.M SHOFIQUZZOHA AND K.K.U AHMED \\ Bangladesh Fisheries Research Institute, Shrimp Research Station, Bagerhat 9300 \\ *Email: matiur.bfri@gmail.com
}

\begin{abstract}
To assess the growth and culture potentials of Indian white prawn Penaeus indicus, locally known as Chaka Chingri, a preliminary trial was conducted for a period of 145 days in earthen ponds. The post larvae were collected from Sundarbans coast and stocked in 3 ponds of 0.056 ha each with the stocking density at 30, 40 and $54 \mathrm{~m}^{-2}$ in $\mathrm{T}_{1}, \mathrm{~T}_{2}$ and $\mathrm{T}_{3}$ treatments respectively. Commercial pelleted feed with $36 \%$ protein was fed. Production and physico-chemical parameters were recorded and analyzed according to standard methods. After 145 days of rearing, obtained average final weight was $22.18 \pm 6.71 \mathrm{~g}, 25.25 \pm 3.11 \mathrm{~g}$ and $29.25 \pm 2.88 \mathrm{~g}$; with the estimated yield of $1197 \mathrm{~kg} / \mathrm{ha}, 3030 \mathrm{~kg} / \mathrm{ha}$, and $3632 \mathrm{~kg} / \mathrm{ha}$, survival was $18 \%$, $30 \%$ and $23 \%$ in $\mathrm{T}_{1}, \mathrm{~T}_{2}$ and $\mathrm{T}_{3}$ treatments respectively. Results and findings of the present study suggested that $P$. indicus might be potential mariculture candidate in the coastal areas of Bangladesh.

Keywords: Penaeus indicus, Culture, Stocking density
\end{abstract}

\section{Introduction}

Shrimp industry is one of the important contributors of strengthening economy, employment generation and poverty reduction in Bangladesh. Since the last decades, this sector has been suffering from various issues and problems related to culture and production due to changing climate, disease and pollution. The two main commercial important shrimp/prawn species in Bangladesh are Penaeus monodon for brackish and marine water and Macrobranchium rosenbergii for freshwater. P. monodon is facing devastating crop loss in each year due to disease outbreak. Diversification of species is imperative for sustainable shrimp production, and Indian white shrimp $P$. indicus is considered to be a potential candidate for shrimp aquaculture (Parado-Estepa et al. 1987). P. indicus is widely distributed in the Indo-West Pacific from the south and eastern Africa to northern Australia including the Indian coast and Red sea (Carpenter and Niem 1998, Fischer and Bianchi 1984). Closing the life cycle of $P$. indicus and its domestication as well as rearing through several generations have been successful (Bukhari et al. 1997, Kumlu and Jones, 1995).The shrimp mature and breed mostly in marine habitats and spend the juvenile and sub-adult stages in coastal estuaries, backwaters or lagoons. $P$. indicus is euryhaline, continues to grow in prolonged confinement and attains very large size in brackish water enclosures. Juveniles can tolerate a much wider range of salinity $(5-40 \mathrm{ppt})$ than adults (FAO 2018).In the southwest coast of India the juveniles support a good commercial fishery in the backwaters and paddy fields (CIBA 2018). The present study was performedto observe the growth, survival and production potentials of $P$. indicus under different stocking densities in earthen ponds. 


\section{CULTURE POTENTIAL OF INDIAN WHITE PRAWN}

\section{Materials and Methods}

Collection of baseline information: Baseline information regarding traditional culture practices of chaka chingri was collected through a pretested questionnaire survey in 2019. Sampling was done in Bagerhat sadar, Mongla, Rampal, Shoronkhola and Morelgonj upazila of Bagerhat district as well as Batiaghata upazila of Khulna district. A total of 60 sets of data were collected through direct personal interview and using Focus Group Discussion (FGD) tool with different stakeholders. Sampling frequencies were twice in every month from February to April 2019.

Pond selection and preparation: The culture experiment was conducted in tide fed three earthen ponds of Shrimp Research Station under Bangladesh Fisheries Research Institute. The ponds had an area of 0.056 ha each with a water depth of $1 \mathrm{~m}$. The ponds were prepared bydrying, removing of unwanted sludge and repairing of embankments .Lime was applied at the rate of $250 \mathrm{~kg} / \mathrm{ha}$ in the ponds and left for seven days. Ponds were filled with tidal water from the Daratana river during high tide and left for 3 days to settle down. Pond water was fertilized with compost cow dung@1,250kg/ha, urea @37.5kg/ha and TSP @25kg/ha. These ponds were left for 10 days to promote primary food production.

Collection and stocking of PL: The wild post larvae (PL) were collected from the Sibsha River of Khulna districts adjacent to the Sundarbans mangrove forest, acclimatized and stocked in the pond in March, 2019.

Feed and feeding management: The shrimps were fed with commercial CP prawn feed with $36 \%$ protein level. Initially feed was provided at $13 \%$ of biomass of post larvae and subsequently decreased to $2.5 \%$. Feed was adjusted periodically in accordance with the growth performance, total biomass and assuming $100 \%$ survival of $P$. indicus. Feeding schedule was twice in a day at dawn and dusk for the first month, while it was once in day for the rest of culture period. Feed was provided on 5 feeding trays having an area of $1 \mathrm{~m}^{2}$ each. The feed trays were hanged to the bamboo poles and allowed to submerge in the water column. Pond water was fertilized with urea $(37 \mathrm{~kg} / \mathrm{ha})$ and TSP $(25 \mathrm{~kg} / \mathrm{ha})$ at 15 days interval to enhance natural foods, whereas limed with calcium carbonate at the rate of $65 /$ ha at 15 days intervals to maintain congenial water quality.

Monitoring of physico-chemical water parameters: The physico-chemical parameters of pond water were monitored at 9:00to 10:00AMin every 7 days. Water quality parameters like water temperature $\left({ }^{\circ} \mathrm{C}\right), \quad \mathrm{DO}(\mathrm{mg} / \mathrm{l}), \mathrm{CO}_{2}(\mathrm{mg} / \mathrm{l})$, total alkalinity $(\mathrm{mg} / \mathrm{l}), \mathrm{pH}$, iron $(\mathrm{mg} / \mathrm{l})$,ammonia $(\mathrm{mg} / \mathrm{l})$ was monitored using $\mathrm{HACH}$ Kit Box. Transparency $(\mathrm{cm})$ was measured by using secchi disc and water depth $(\mathrm{cm})$ was measured manually by using meter scale.

Monitoring of growth and estimation of production: Health condition and growth of shrimp was monitored fortnightly during the full and new period. At least 5\% of shrimp was collected by a cast net in early morning. Length was measured by using a centimeter scale and theweight by a portable weighing balance. After 145 days of rearing, all shrimp were harvested with seine net and the following parameters were calculated: 
Average weight gain $(\mathrm{g})=$ Mean final weight (b) - mean initial weight (a); Specific growth rate SGR (\%body wt. gain/day) $=\left[\left(\log _{\mathrm{n}}\right.\right.$ Final wt.- $\log _{\mathrm{n}}$ Initial wt. $) /$ Time interval $\left.] \times 100\right)$; Survival $(\%)=($ Number of fish harvested/Number of fish stocked $) \times 100$; Production/Yield $(\mathrm{kg} / \mathrm{ha})=[\{$ Number harvested $\times$ average final wt. $(\mathrm{g}) / 1000] \times$ pond area $(\mathrm{ha})$; and Food conversion ratio $(\mathrm{FCR})=$ Supplied feed $(\mathrm{kg}) /$ harvested total biomass $(\mathrm{kg})$.

Data analysis: Comparison of treatment mean was carried out using one-way analysis of variance (ANOVA), followed by Duncan's Multiple Range Test. Significance at the 5\% level $(p<.05)$ using the SPSS (Statistical Package for Social Science) version-20.

\section{Results}

Baseline information: Information regarding traditional culture practices and production of Indian White Shrimp are presented in Table I. Farmers stock chaka chingri during February to March with a very low density of 150/decimal. They follow mixed culture system with other shrimp and finfishes. Sometimes they follow integrated culture with paddy and dyke cropping with seasonal vegetables. Though they never keep records on production of specific species but harvested variety of native shrimp species including Indian White Prawn those entered through tidal water (Table I).

Growth, survival, stoking and harvesting details of $P$. indicus juveniles at the end of 145 days are detailed in this section. Recorded water quality parameters are also reported. The initial weight of $P$. indicus was $0.0123 \mathrm{~g}$ and stocking densities were $30 / \mathrm{m}^{2}, 40 / \mathrm{m}^{2}, 54 / \mathrm{m}^{2}$ in $\mathrm{T}_{1}, \mathrm{~T}_{2}$, and $\mathrm{T}_{3}$ treatments respectively (Table II). After culturing 145 days the average body weights were $22.18 \pm 6.71 \mathrm{~g}, 25.25 \pm 3.11 \mathrm{~g}$ and $29.25 \pm 2.88 \mathrm{~g}$, with a specific growth rate of $5.31 \%, 5.40 \%$, and $5.50 \%$ in $\mathrm{T}_{1}, \mathrm{~T}_{2}$, and $\mathrm{T}_{3}$ respectively. The percentage of survival was $18 \%, 30 \%$, and $23 \%$ in $\mathrm{T}_{1}, \mathrm{~T}_{2}$, and $\mathrm{T}_{3}$ respectively. The mean FCR value was $1.05,0.99$, and 1.04 which indicates feed consumption was comparatively lower in $\mathrm{T}_{2}$ treatments $(p<.05)$.

Table I. Present status of traditional culture practice of $\boldsymbol{P}$. indicus in coastal districts

\begin{tabular}{ll}
\hline Questions & Responses \\
\hline Source of PL & Coastal river adjacent to mangrove forest \\
Time of PL collection & February/March \\
Stocking & February/March \\
Stocking density & 150 PL/ decimal \\
Type of stocking & Artificial or Tidal auto-stocking (Chaka chingri 5\%-10\%) \\
Culturesystem & Mixed (shrimp+white fishes) and Intregated (paddy+ vegetables + fishes) \\
Culture period & $1.5-3$ months \\
Time of harvest & April/May \\
Constraint & Water Crisis, Poor Salinity level, PL Death, Virus \\
Opportunityneed & Water in dry season, optimum salinity level, available PL \\
Species Found & Chaka, Chali, Motka, Galda, Bagda, Tiger, Goda, Horina, Rosni, Juboti, \\
& Chamti, Galangi,Kathali \\
Decreasing species & Chaka, Goda, Kathali \\
\hline
\end{tabular}




\section{CULTURE POTENTIAL OF INDIAN WHITE PRAWN}

According to APHA (2005) and Boyd and Fast (1992) recorded all physico-chemical variables like dissolved oxygen, $\mathrm{pH}$, alkalinity, ammonia, nitrite, iron and transparency; were found within the acceptable ranges for crustacean aquaculture except the lower salinity levels in $T_{1}, T_{2}$, and $T_{3}$ treatments respectively during the entire culture period (Table III).

Table II. Effect of stoking density on growth, survival and production performance of Penaeus indicus in earthen ponds*

\begin{tabular}{lccc}
\hline Particulars & $\mathbf{T}_{\mathbf{1}}\left(30 / \mathrm{m}^{2}\right)$ & $\mathbf{T}_{\mathbf{2}}\left(40 / \mathrm{m}^{2}\right)$ & $\mathbf{T}_{\mathbf{3}}\left(54 / \mathrm{m}^{2}\right)$ \\
\hline Mean length at stocking $(\mathrm{cm})$ & 0.5 & 0.5 & 0.5 \\
Mean weight at stocking $(\mathrm{g})$ & 0.01 & 0.01 & 0.01 \\
Survival rate $(\%)$ & $18 \%^{\mathrm{a}}$ & $30 \%^{\mathrm{a}}$ & $23 \%^{\mathrm{a}}$ \\
Production rate* $(\mathrm{kg} / \mathrm{ha})$ & $1197^{\mathrm{a}}$ & $3030 \mathrm{~b}$ & $3632^{\mathrm{b}}$ \\
Mean length at harvest $(\mathrm{cm})$ & $16.88 \pm 2.20$ & $20.95 \pm 1.70$ & $24.33 \pm 3.47$ \\
Mean weight at harvest $(\mathrm{g})$ & $22.18 \pm 6.71^{\mathrm{a}}$ & $25.25 \pm 3.11^{\mathrm{a}}$ & $29.25 \pm 2.88$ \\
SGR $(\%$ day) & $5.31 \%^{\mathrm{a}}$ & $5.40 \%^{\mathrm{a}}$ & $5.50 \%^{\mathrm{a}}$ \\
Total feed given $(\mathrm{kg})$ & 63 & 150 & 190 \\
Total biomass produced $(\mathrm{kg})$ & 60 & $151^{\mathrm{a}}$ & 181.5 \\
Feed conversion ratio & $1.05^{\mathrm{a}}$ & $0.99^{\mathrm{b}}$ & $1.04^{\mathrm{a}}$ \\
\hline
\end{tabular}

$*$ Different superscript letters within the same row indicate a significant difference $(p<.05)$

Table III. Recorded water quality parameters of culturing $\boldsymbol{P}$. indicus in the earthen ponds*

\begin{tabular}{lccc}
\hline Parameters & $\mathbf{T}_{1}($ Mean + SD) & $\mathbf{T}_{2}($ Mean + SD & $\mathbf{T}_{3}($ Mean + SD \\
\hline Temperature $\left({ }^{\circ} \mathrm{C}\right)$ & $29.72 \pm 2.68^{\mathrm{a}}$ & $28.72 \pm 3.44$ & $27.72 \pm 2.99$ \\
Dissolved Oxygen $(\mathrm{mg} / \mathrm{l})$ & $5.90 \pm 1.13^{\mathrm{a}}$ & $5.00 \pm 1.17^{\mathrm{a}}$ & $4.99 \pm 1.36^{\mathrm{a}}$ \\
$\mathrm{pH}$ & $8.25 \pm 0.21^{\mathrm{a}}$ & $8.05 \pm 0.24^{\mathrm{a}}$ & $8.50 \pm 0.61^{\mathrm{a}}$ \\
Salinity (ppt) & $3.09 \pm 1.20^{\mathrm{b}}$ & $4.23 \pm 1.88^{\mathrm{b}}$ & $3.77 \pm 1.45^{\mathrm{b}}$ \\
Alkalinity (mg/l) & $124.0 \pm 17.68^{\mathrm{a}}$ & $134.0 \pm 19.60^{\mathrm{a}}$ & $140.0 \pm 20.10^{\mathrm{a}}$ \\
Ammonia (mg/l) & $0.30 \pm 0.04^{\mathrm{a}}$ & $0.30 \pm 0.05^{\mathrm{a}}$ & $0.30 \pm 0.07^{\mathrm{a}}$ \\
Nitrite (mg/l) & $0.03 \pm 0.01^{\mathrm{a}}$ & $0.07 \pm .03^{\mathrm{a}}$ & $0.09 \pm .02^{\mathrm{a}}$ \\
Iron (mg/l) & $0.4 \pm 0.20^{\mathrm{a}}$ & $0.5 \pm 0.30^{\mathrm{a}}$ & $0.8 \pm 0.10^{\mathrm{a}}$ \\
Transparency (cm) & $25.46 \pm 1.36^{\mathrm{a}}$ & $35.56 \pm 1.16^{\mathrm{a}}$ & $30.40 \pm 1.77^{\mathrm{a}}$ \\
\hline
\end{tabular}

*Different superscript letters within the same column indicate a significant difference $(p<.05)$. All the values were reported as mean with standard deviation.

\section{Discussion}

Semi-intensive farming of $P$. indicus was first introduced in late 1980s in India with stocking density of 50-100 PL/m $\mathrm{m}^{2}$ and feeding with artificial diets which augmented the production from 10000 to $20000 \mathrm{~kg} / \mathrm{ha} / \mathrm{yr}$ (CIBA 2018). In the present experiments, the estimated yield of $P$. indicus was achieved $1197 \mathrm{~kg} / \mathrm{ha}, 3030 \mathrm{~kg} / \mathrm{ha}$ and $3632 \mathrm{~kg} / \mathrm{ha}$ from $3.09 \pm 1.20 \mathrm{ppt}, 4.23 \pm 1.88$ ppt and $3.77+1.45 \mathrm{ppt}$, salinities in $\mathrm{T}_{1}, \mathrm{~T}_{2}$, and $\mathrm{T}_{3}$ treatments respectively. The yield of $\mathrm{T}_{2}$ showed significant difference $(p>0.05)$ with $\mathrm{T}_{3}$ and $\mathrm{T}_{1}$ treatments $(p<0.05)$ is therefore supported by the observations of Mohan and Nandakumaran (1980) who reported a production of $500 \mathrm{~kg} / \mathrm{ha}$ for 112 days with a survival rate of $48 \%$. Jones and Salama (1997) found higher growth of Indian White Prawn in salinity ranged between 25-50 ppt. They also found reduced 
growth and survival in moderate to low ( $<15 \mathrm{ppt})$ salinities. Kumlu and Jones (1995) also reported poor survival $(13.3 \%)$ at $10 \mathrm{ppt}$ and recommended the optimum salinity level between 20 and $30 \mathrm{ppt}$ for culture of Indian White Prawn. The manifestation of salinity stress and low survival at salinities lower than $10 \mathrm{ppt}$ have also been reported by Parado-Estepa et al. (1987) and Primavera (1984). However, survival and production records of $P$. indicus at low salinities are often debated and have different doctrines and disagreements. Production of aquaculture species vary with stocking density, quality of feed used, productivity of watershed, water quality management and influence of various external factors. In this study, the yield of $P$. indicus obtained $1197 \mathrm{~kg} / \mathrm{ha}, 3030 \mathrm{~kg} / \mathrm{ha}$ and $3632 \mathrm{~kg} / \mathrm{ha}$ with stocking densities of $30 / \mathrm{m}^{2}, 40 / \mathrm{m}^{2}$ and $54 / \mathrm{m}^{2}$ in $\mathrm{T}_{1}, \mathrm{~T}_{2}$, and $\mathrm{T}_{3}$ treatments respectively within 145 days of culture is in agreement with the production record of $500 \mathrm{~kg} / \mathrm{ha}$ for 112 days of culture with $18.5 \mathrm{~m}^{2}$ stocking densities and $48 \%$ recovery rates (Mohan and Nandakumaran 1980).In another experiment they also reported a production of $1,600 \mathrm{~kg} / \mathrm{ha}$ for 110 days with a survival rate of $98 \%$ when the prawns were stocked at $42 \mathrm{~mm}$ mean size and a stocking density of $19 / \mathrm{m}^{2}$. During the present experiments, only $18 \%, 30 \%$ and $23 \%$ survival at the stocking rate of $30 / \mathrm{m}^{2}, 40 / \mathrm{m}^{2}$ and $54 / \mathrm{m}^{2}$ in $\mathrm{T}_{1}, \mathrm{~T}_{2}$, and $\mathrm{T}_{3}$ treatments respectively were obtained. whereas Lazarus et al. (1986) reported a good survival rates $(86.7$ and $89.8 \%)$ in this culture system when the stocking density was $6.4 / \mathrm{m}^{2}$ and $7.1 / \mathrm{m}^{2}$ and poor survival rates of 7.9 and $3.6 \%$ when the stocking density was $30.5 / \mathrm{m}^{2}$ and $38.0 / \mathrm{m}^{2}$ respectively. By rearing the wild stock of $P$. indicus for 145 days the harvest size was $16.88 \pm 2.20 \mathrm{~cm}, 20.95 \pm 1.70 \mathrm{~cm}$ and $24.33 \pm 3.47 \mathrm{~cm}$, in $\mathrm{T}_{1}, \mathrm{~T}_{2}$, and $\mathrm{T}_{3}$ treatments respectively showed better growth in a shorter time. In the normal course when the prawns are stocked at a larger size, the survival rates are expected to be good. Mohan and Nandakumaran (1980) got only $48 \%$ survival rate for the $P$. indicus which were stocked at an average size of $42 \mathrm{~mm}$. This poor survival rate may be attributed to the higher stocking density $\left(18.5 / \mathrm{m}^{2}\right)$. The higher survival rate reported by (Lazarus et al. 1988) for the prawns which were stocked at a mean size of 46.6 and $84.0 \mathrm{~mm}$ but at a low stocking density $\left(6.4\right.$ and $\left.7.1 / \mathrm{m}^{2}\right)$ lend to support that stocking densities has important role in growth and survival.

Temperature and salinity variations are considered the most important factors influencing the growth and survival of shrimps. According to Rahman et al. (2017) in the month of AprilMay these ponds were shown to have too low water depth to resist abrupt change in water temperature maximum $36^{\circ} \mathrm{C}$ that creates stress in survivility. Shrimp PL death may be due to the low water depth, rapid fluctuation of water level. The values of transparency $25.46 \pm 1.36$ $\mathrm{cm}, 35.56+1.16 \mathrm{~cm}$ and $30.40 \pm 1.77 \mathrm{~cm}$ were recorded in $\mathrm{T}_{1}, \mathrm{~T}_{2}$, and $\mathrm{T}_{3}$ treatments which indicate that these ponds were less productive and little bit turbid. Salinity represents the total concentration of dissolved inorganic ions or salts in water. The mean salinity was $3.09 \pm 1.20$ ppt, $4.23+1.88 \mathrm{ppt}$ and $3.77+1.45 \mathrm{ppt}$ in $\mathrm{T}_{1}, \mathrm{~T}_{2}$, and $\mathrm{T}_{3}$ treatments respectively. Shrimp shell become soften because of low salinity of water where the presence of carbonates/ bicarbonates are poor which accelerate shrimp PL death (Islam et al., 2014). The increase in the feed conversion ratio as the prawns grow larger in many of the ponds may be due to excess feeding as the quantity of feed was determined based on the original number stocked. This can be avoided by feeding the stock after periodically assessing the actual biomass present in the pond. However, the results obtained in the present experiments with $P$. indicus are almost in agreement with the results of Elam and Green (1974), on $P$. indicus using two different feeds in nursery and grow-out ponds. They obtained production rates of 224 to $667 \mathrm{~kg} / \mathrm{ha}$, with feed conversion ran-going from 1.8 to 2.3 . In the present studythe yield of $P$. indicus was achieved 
CULTURE POTENTIAL OF INDIAN WHITE PRAWN

$1197 \mathrm{~kg} / \mathrm{ha}, 3030 \mathrm{~kg} / \mathrm{ha}$ and $3632 \mathrm{~kg} / \mathrm{ha}$ was obtained in 145 days period with a feed conversion value of 1.05, 0.99 and 1.04 in $\mathrm{T}_{1}, \mathrm{~T}_{2}$, and $\mathrm{T}_{3}$ respectively using commercial pelleted feed.

\section{Literature Cited}

APHA (American public Health Association), 2005. Standard methods for the examination of water and waste water. 21ist ed, APHA, Washington, D.C.

Boyd, C.E and A.W. Fast, 1992. Pond monitoring and management in marine shrimp culture: Principles and practices In: Fast, A.W. and Lister, L.J. (eds.). Elsevier. pp. 497-508.

Bukhari, F., D. Jones and A. Salama, 1997. Optimal salinities for the culture of Penaeus indicus from the Red Sea. J. King Abdulaziz Univ., 8 (1), 137-147.

Carpenter, K.E. and V.H. Niem, 1998. FAO species identification guide for fishery purposes. The living marine resources of the Western Central Pacific, Vol. 2. Cephalopods, crustaceans, holothurians and sharks. Rome, Italy: Food and Agriculture Organization of the United Nations, 971p.

CIBA, 2018. Annual Report 2017-18. Central Institute of Brackishwater Aquaculture, Chennai, Tamil Nadu, India. Publication, ISSN 0976-5536, 250 p.

FAO, 2018. Cultured Aquatic Species Information Programme - Penaeus indicus (H. Milne Edwards, 1837). FAO Fisheries \& Aquaculture- 2018. http://Www.fao.org/fishery/ culturedspecies/Penaeus indicus/en

Fischer, W. and G. Bianchi, 1984. FAO species identification sheets for fishery purposes: Western Indian Ocean (Fishing Area 51). Vol. 1. Rome, Italy: 513 p.

Islam, R., M H Khan, D. Roy, M. M. Alam, K. K. U. Ahmed, Y. Mahmud, M. N. Ahasan, and M. S. Shah, 2014. Association of risk factors: WSSV proliferation in the shrimp (Penaeus monodon) farms of south-west coastal region of Bangladesh Ann. Vet. Anim. Sci., 1(1): 39-51.

Larry L. A. Elam and W. Green, 1974. Culture of white shrimp (Penaeus setiferus, Linnaeus) in static water ponds. J. World Aquac. Soc., 5(1-4): 87-97.

Kumlu, M. and D.A. Jones, 1995. Salinity tolerance of hatchery-reared postlarvae of Penaeus indicus $\mathrm{H}$. Milne Edwards originating from India. Aquaculture, 130 (2-3): 287-296.

Lazarus. S, M.S. Muthu, K. Nandakumaraand S.A. Ali, 1988. Experimental field culture of white prawn, Penaeus indicus, in the polyethylene film-lined ponds using pelletised feed. Indian J. Fish.,35 (3): 171-177.

Mohan, R.S.L. and K. Nandakumaran, 1980. Possibility of using polythene lined ponds for mariculture in sandy beaches. Marine Fisheries Information Service. Technical and Extension Series. Central Marine Fisheries Research Institute, Couchin, India. No. 26: 6-8.

Parado-Estepa, F.D., R.P. Ferraris, J.M. Ladja and E.G. De Jesus, 1987. Responses of intermolt Penaeus indicus to large fluctuations in environmental salinity. Aquaculture, 64 (3): $175-184$.

Primavera, J.H., 1984. Potentials of Putian. Asian Aquac., 6 (6): 4-6.

Rahman, M.M., M.A. Islam, H.M.R. Islam and K.K.U. Ahmed, 2017. Present status of low depth shrimp farming system with special reference to soil-water characteristics in southwest region of Bangladesh. J. Agric. Ecol. Res. Int., 12(1): 1-18. 